\title{
What causes willow die-off?
}

\section{A Montana study looks at the relationship between stem cankers and browsing.}

\author{
By Ryan Limb, Clayton B. Marlow and Barry Jacobson
}

In riparian areas, willow (Salix spp.) has been identified as a key species for stream health, bank stability, vegetative filter zones and the winter survival of deer, elk, moose, beaver, hares, and ptarmigan. Consequently, the sustainability of individual willows and willow communities is fundamental to both the functioning of riparian ecosystems and the maintenance of certain wildlife populations.

While we may recognize the linkage between willow survival and that of dependant wildlife species, we know little about the factors that govern reproduction, establishment, and long-term presence of willows in riparian ecosystems.

Like many other woody plant species, willows are susceptible to diseases including cankers caused by fungi that enter the plant through wounds. Bark wounds can occur from browsing, hail, strong winds, frost or a host of other agents. Once infected, the plant develops a canker that begins to girdle the stem at the site of infection (Fig. 1).

Information on aspen ecology from the US Forest Service indicates that while minor canker infections kill the tissue surrounding the wound, the remainder of the stem's transport tissue (xylem and phloem) will remain alive and functioning. However, if the infection grows or the plant is repeatedly infected, the canker will girdle the stem resulting in death of that stem. This event is commonly called ringing. The heavily infected stem can no longer transport nutrients past the canker to leaves or buds, and the stem soon dies and falls to the ground. The loss of numerous stems will stunt the growth of the plant and if the losses are sufficiently large, the plant may eventually die. Because quaking aspen (Populus tremuloidies) is in the same family as willows, we could use this information to predict that stem injuries may lead to canker infections in willows. Severe infections could lead to the loss of numerous willows in a riparian area.

Due to the heightened awareness of the crucial role willows play in riparian ecosystems, it is important for federal, state, and private land managers to know the cause of willow die-off. Even though there are reports of willow die-offs due to declining water tables in eastern California, overuse by wildlife in Wyoming and Colorado and heavy livestock grazing throughout the West, there are very

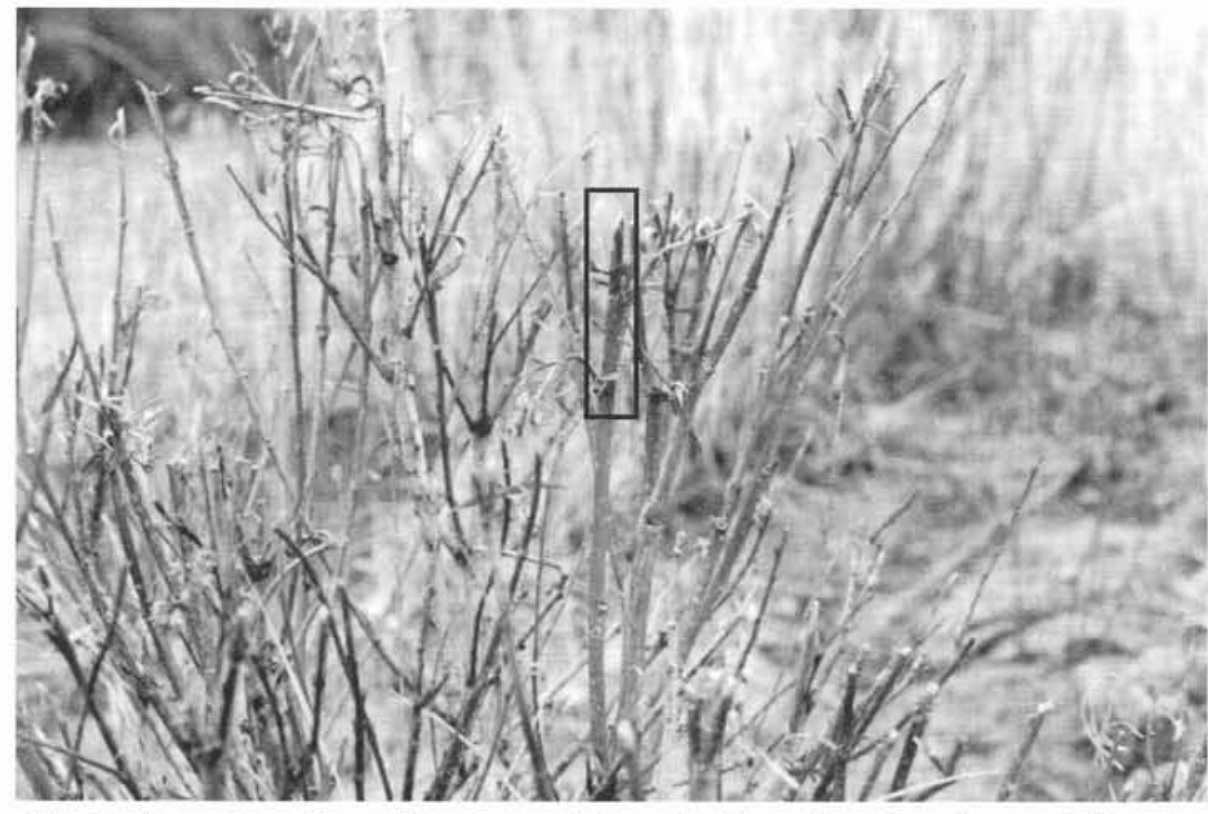

Fig. 1. Several sandbar willow stems infected with canker. Boxed area indicates stem already dead from canker ringing. 


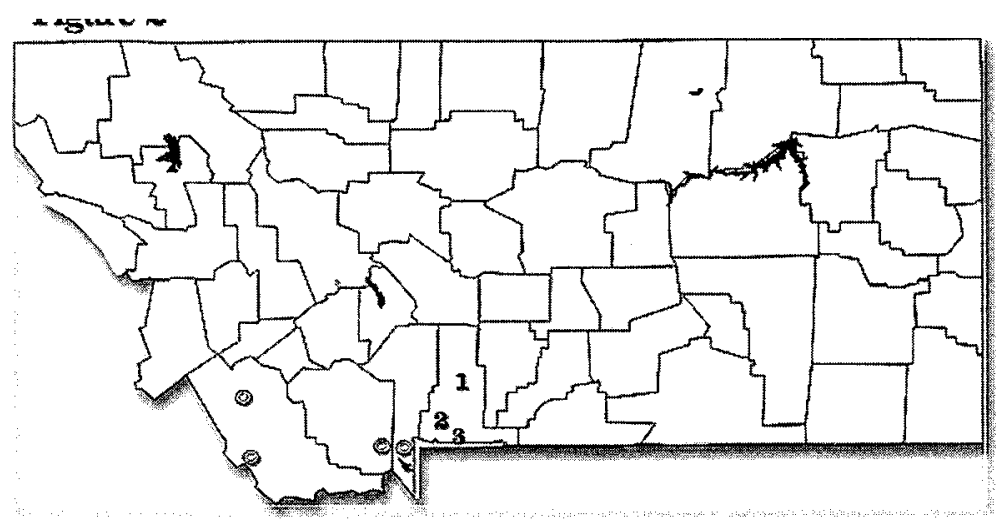

Fig. 2. Willow collection sites in the upper Yellowstone Valley, Park County, Montana. $1=$ Yellowstone River island, $2=$ Tom Miner Creek, $3=$ Eagle Creek and $0=$ observation sites.

few documented cases of willow losses from disease outbreaks.

Because the ecological literature on willow diseases is limited, we initiated a descriptive study to: a) determine the level of pathogenic fungi infestation of willows in the upper Yellowstone Valley of southwestern Montana and b) describe the relationship between fungal infestation and browsing levels. The anticipated outcome of this study would be a list of canker causing pathogenic fungi on willows, and whether or not a relationship exists between browsing and fungi infestation.

\section{A Study To Determine Canker Infection}

Because of the potential for canker infestations following browsing three riparian areas with high wildlife activity were selected as collection sites (Fig. 2). At each of the three sites individuals of Booth (Salix boothi Dorn), Sandbar (Salix exigua Nutt), Geyer (Salix geyeriana Anderss) and Yellow (Salix lutea Nutt) were randomly selected within a $1.25 \mathrm{ac}$ area.

Once the identity of the willow was known, browse level was described for each of the selected plants following procedures described in the Forest Service and BLM Interagency Technical Reference Guide. Table 1 displays the categories used and the

Table 1. Browse classes used to assign level of willow use by wildlife.

\begin{tabular}{|llc|}
\hline Class & General Description & Percent Use \\
\hline 0 & Little to no browsing & $<25 \%$ \\
\hline 1 & Lightly browsed & $25-50$ \\
\hline 2 & Moderately browsed & $50-75 \%$ \\
\hline 3 & Heavily browsed & $>75 \%$ \\
\hline
\end{tabular}

estimated level of use assigned to each category. A total of 81 stems with cankers were collected from all three locations (Table 2).

Table 2. Location of willow collection sites in southwestern Montana, number of cankered stems collected, willow species encountered and browse levels for plants from which collections were made.

\begin{tabular}{|lccc|}
\hline Collection Site & Samples & Species & Number in Each Browse Class \\
\hline Eagle Creek & 31 & $\begin{array}{c}\text { Sandbar } \\
\text { Geyer }\end{array}$ & $\begin{array}{c}19 \text { - class 3 } \\
12 \text { - class 3 }\end{array}$ \\
\hline Yellowstone River & 25 & $\begin{array}{c}\text { Sandbar } \\
\text { Booth }\end{array}$ & 15 - class 3 \\
Island & & - class 3 \\
\hline Tom Miner Creek & 25 & Geyer & 19 - class 3 \\
& & Booth & 3 - class 2 \\
& & Yellow & 3 - class 1 \\
\hline
\end{tabular}

To isolate fungi associated with cankers, clippings were taken from cankered stems no more than three years old (Fig. 3). This was done to avoid past infections that might have healed. Stems were harvested so that a healthy section was included with the canker to provide similar genetic material for sprouting at a later date. Healthy portions of the stems were separated from dead and cankered material, placed in a plastic pail with 4 inches of dechlorinated water and set in a greenhouse with a twelve hour photoperiod and temperature ranging from $72-75^{\circ} \mathrm{F}$. The stems were allowed to sprout roots and produce leaves.

Cankered sections were placed in a storage container at $100 \%$ humidity and $70^{\circ} \mathrm{F}$ for 21 days. Isolations of fungi were made by removing a 0.25 square inch section of infected tissue from the margin of the canker, and partially embedding it in acidified agar. Fungi were allowed to grow on the agar for one week. New cultures were made from these plates to establish pure cultures for fungi identification. 


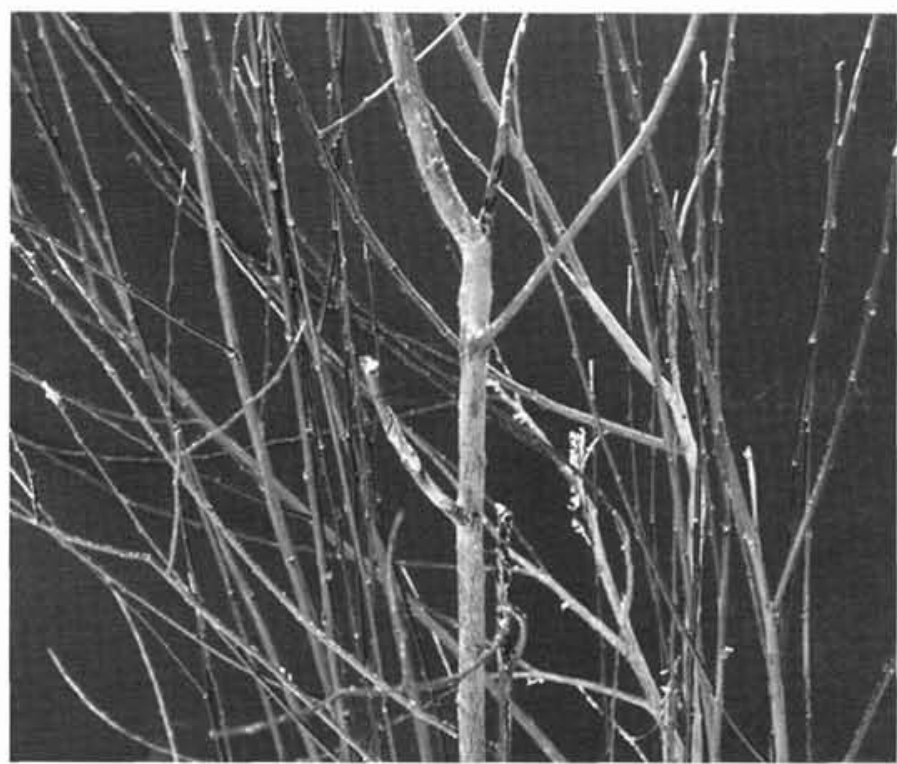

Fig. 2. Appearance of healthy (non-cankered) stems, placed in greenhouse for rooting. Stems were from infected willows to avoid canker resistance due to genetic variation.

After one week the pure cultures were examined and fungi identified to the genus level through microscopic analysis of fruiting body and spore type. Once the cultures began to sporulate, some of the spores were removed with a metal probe and used to re-infect the original, healthy portion of the willow growing in the greenhouse. All of healthy stems had developed roots and leaves by the time of the reinfection.

A small sample of each fungal isolation was placed under the willow's bark. Each bark incision was wrapped in Parafilm ${ }^{(B)}$ and allowed to incubate for 14 days at room temperature. Incisions were also made in several more healthy willow stems which were then incubated without spore inoculation for use as controls.

If a canker formed on the infected willow stem, isolation of the fungal material was performed as previously described. To ensure that the same fungi species were from the original source isolates were examined according to standard plant pathology diagnostic procedures.

\section{What Was Learned?}

Twenty-one different types of fungi were isolated from the infected willow stems but, only seven (Table 3 ) were found to cause cankers following inoculation of the live stems (none of the controls with incisions developed cankers). This indicates that Arthrobotrys, Tubercularia, Aspergillus, Cylindrocladium, Cytospora, Dothichiza, and Coniothyrium can be infectious to willows.

In the Eagle Creek drainage near the northern border of Yellowstone National Park, sandbar, Booth and Geyer willow all showed signs of heavy browsing (Table 2). Corresponding with this heavy browsing, nearly all browsed branches and stems showed canker infection symptoms. The same relationship was noted on the island site in the main stem of the Yellowstone River. Both sandbar and Booth willows had been browsed heavily (Table 2) and all the branches had canker infections.

The situation was different at the Tom Miner Creek site where willows showed signs of heavy (Geyer), moderate (Booth) and light (yellow) browsing (Table 2). Lightly browsed willows only had occasional stem infections while the majority of stems on the heavier utilized plants were cankered. Statistical analysis of the Tom Miner Creek data indicted that browse class and the level of stem cankering were closely related.

The results from this survey indicate that several canker-causing fungi are present on willow samples in the upper Yellowstone Valley. The close relationship between the level of browsing and the occurrence of cankers at one collection site suggests that heavily browsed willows may be more susceptible to fungal invasion and therefore more prone to rapid and complete die offs than lightly used shrubs. However, carefully controlled studies are needed to determine the degree to which browsing increases willow susceptibility to fungal infection and die-off.

Table 3. Pathogenic fungi found on browsed willows in the Yellowtone valley of southwestern Montana. Values represent proportion of total fungal population isolated from indiviudal willow stems.

\begin{tabular}{|lc|}
\hline Fungi & $\begin{array}{c}\text { Percent of } \\
\text { Collections }\end{array}$ \\
\hline Arthrobotrys & 36 \\
\hline Tubercularia & 15 \\
\hline Aspergillus & 7 \\
\hline Cylindrocladium & 4 \\
\hline Cytospora & 3 \\
\hline Dothichiza & 3 \\
\hline Coniothyrium & 1 \\
\hline
\end{tabular}


Our observations indicate that once a stem or branch was infected with a canker causing fungi, the branch began to die from the point of infection back toward the main stem of the shrub. Most often, 1-2 inches was killed, but 4.5- 45 inches of die back was noted on several heavily browsed plants in the Eagle creek area.

Review of historic grazing records indicated that the three locations we selected had not been grazed by livestock prior to stem collection. Tom Miner Creek has a rotational livestock grazing system, but cattle had been absent for two years. The US Forest Service records show that livestock were removed from Eagle Creek in the 1930's and the island within the main branch of the Yellowstone River has not had livestock grazing.

Wildlife, primarily deer, elk and moose were responsible for the browsing at all three locations. This suggests that wildlife induced disease outbreaks could have limited willow populations along streams and rivers prior to European settlement. Among riparian processes stream channel stability would have been most affected by how extensive these die-offs were and how long it took willows to reoccupy former sites.

A general survey of riparian areas outside the Yellowstone river drainage during the summer of 2001 revealed the presence of cankering under heavy browsing conditions. In the Big Hole drainage near Wisdom, Montana, anecdotal evidence suggests that moose were responsible for massive diebacks on similar willow species. As much as 80 inches was noted to have died on one branch (Geyer willow) where heavy browsing had occurred. Similar diebacks are common, although not necessarily as dramatic, in willows occupying the Madison, Gallatin and Beaverhead drainages. All of these drainages are heavily used by wildlife during the winter months.

Looking at the evidence collected thus far, it is obvious that the relationship between browsing and fungal canker infestation in willows should be studied in greater detail. Especially important is how the pathogens are being transported from plant to plant, which wildlife species, if any, are important in fungi transmission, whether infection periods are seasonal and how browsing levels might affect the stem die-off/recruitment rates of commonly occurring willow species.

Authors are respectively, a private consultant working out of Bozeman, Montana, an associate professor, Animal and Range Sciences and a professor, Plant Sciences and Plant Pathology, Montana State University, Bozeman, MT. This work was supported by the Montana State University Undergraduate Research Program and the Montana Agricultural Experiment Station. For more information contact; Clayton Marlow at cmarlow@montana.edu 